\title{
Rediscovery of Saussurea andryaloides (Asteraceae: Cardueae) from Uttarakhand, India
}

\author{
Shruti Kasana, P.L. Uniyal and Arun K. Pandey* \\ Department of Botany, University of Delhi, Delhi-110007, India \\ `E-mail: arunpandey79@gmail.com
}

\begin{abstract}
Saussurea andryaloides (DC.) Sch.Bip. is rediscovered after a gap of 125 years from Uttarakhand. A brief description and illustration is provided here for easy identification.
\end{abstract}

Keywords: India, Rare, Recollection, Saussurea andryaloides, Uttarakhand.

\section{Introduction}

Saussurea DC., one of the species rich genera of the tribe Cardueae (Asteraceae), is represented by $c$. 498 species in the world (Raab-Straube, 2017). The genus includes c. 62 species in India (Hajra, 1998; Butola \& Samant, 2011), however, the diversity is insufficiently inventoried.

During a botanical exploration to the high elevation region of Chopta-Tungnath, Uttarakhand in the Central Himalaya in 2017, the authors came across an interesting specimen of the genus Saussurea. After critical examination by consulting protologue (de Candolle, 1838), type specimen and literature (Clarke, 1876; Hooker, 1881; Hajra, 1998; Shi \& Raab-Straube, 2011), it was identified as $S$. andryaloides belonging to the sect. Strictae C.B. Clarke. The plant was originally described by de Candolle (1838) as Aplotaxis andryaloides DC. based on Royle's collection from northwest India. It was later transferred to the genus Saussurea by Schultz (1846). A thorough survey of literature and herbarium consultation at BSD, DD and $\mathrm{KASH}$, it was found that the taxon has not been collected since 1893 in India despite various surveys conducted in the regions by a number of botanists. Also the recent records of this taxon in the region by various workers (Dhar \& Kachroo, 1983; Chowdhery \& Wadhwa, 1984; Sharma \& Jamwal, 1998; Uniyal et al., 2007; Karthikeyan et

Received: 10.10.2018; Revised \& Accepted: 16.03.2019 Published Online: 31.03 .2019 al., 2009; Pusalkar \& Singh, 2012; Rai et al., 2017) are not supported by recent collections.

Hajra (1998) in his revisionary work mentioned Duthie's collection from Jammu and Kashmir and Kumaun (deposited at DD), which is now more than 125 years old. Hence the present collection marks a rediscovery of $S$. andryaloides after being unrecorded for more than a century. A brief description and illustration is provided here for easy identification of this taxon.

Saussurea andryaloides (DC.) Sch.Bip., Linnaea 19: 331. 1846. Aplotaxis andryaloides DC., Prodr. 6: 542. 1838. Lectotype (designated by Lipschitz 1979): NW INDIA, s.loc., s.d., J.F. Royle s.n. (G00204471 image!).

Saussurea andryaloides (DC.) Hook.f. \& Thomson ex C.B. Clarke, Compos. Ind. 227. 1876, nom. illeg. Figs. $1 \& 2$

Perennial, acaulescent herbs, up to $3 \mathrm{~cm}$ tall. Caudex simple, covered with scars of old leaves. Leaves in rosette, shortly-petioled; lamina linear,

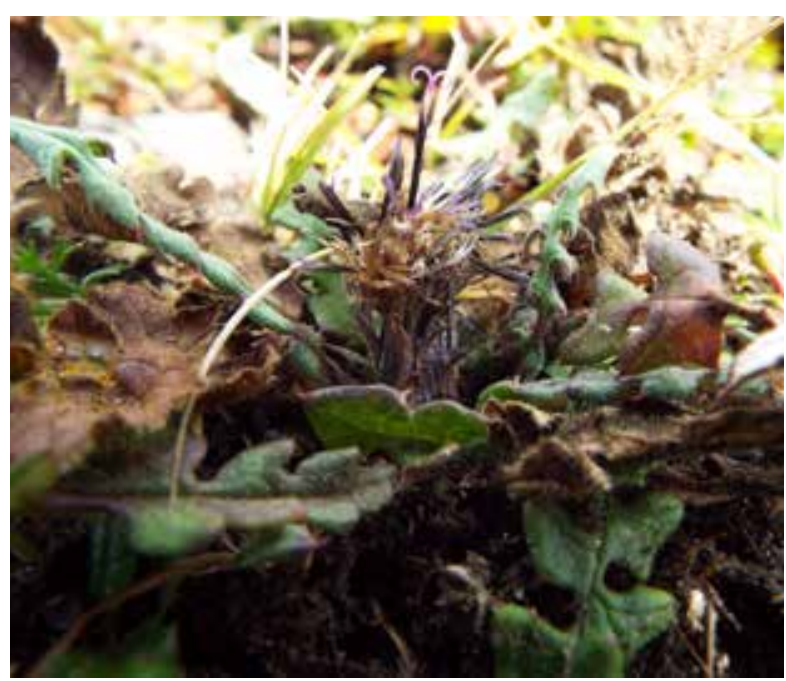

Fig. 1. Saussurea andryaloides (DC.) Sch. Bip.: In bloom (Photo: S. Kasana). 
runcinate, lobes recurved with spiny apex, adaxially green, pubescent, abaxially densely tomentose. Capitula solitary in rosette of leaves, $1.5-2.0 \mathrm{~cm}$ in diam., 2-2.5 cm tall. Phyllaries tri-seriate, purplishred, tomentose, outer ones acuminate at apex, middle ones ovate, acuminate at apex, inner ones lanceolate, acute at apex. Pappus c. $1 \mathrm{~cm}$ long, unior bi-seriate, pale brown, connate at base into a ring, caducous as a whole. Florets numerous, corolla 1.3 $\mathrm{cm}$ long, tube $c .7 \mathrm{~mm}$ long, limb (including lobes) c. $5 \mathrm{~mm}$ long, purplish-red, glabrous. Anthers c. 7.5 $\mathrm{mm}$ long, tails woolly, fimbriate. Achene $3.5 \mathrm{~mm}$ long, cylindrical, brownish, glabrous, distinctly ribbed, with a short crown at apex.
Flowering \& fruiting: August-October.

Ecology \& habitat: Grows in alpine Himalaya, at an elevation ranging from 3200 to $5400 \mathrm{~m}$. The species was found to be sparsely distributed and only few individuals were recorded.

Distribution: China, India (Himachal Pradesh, Jammu \& Kashmir, Sikkim, Uttarakhand) and Pakistan. In all relevant literature, the species was reported only from northwest Himalaya in India. However, during the present investigation it was found that it has also been collected from Sikkim by Hooker (P00258217), which forms a new addition to the Flora of Sikkim.

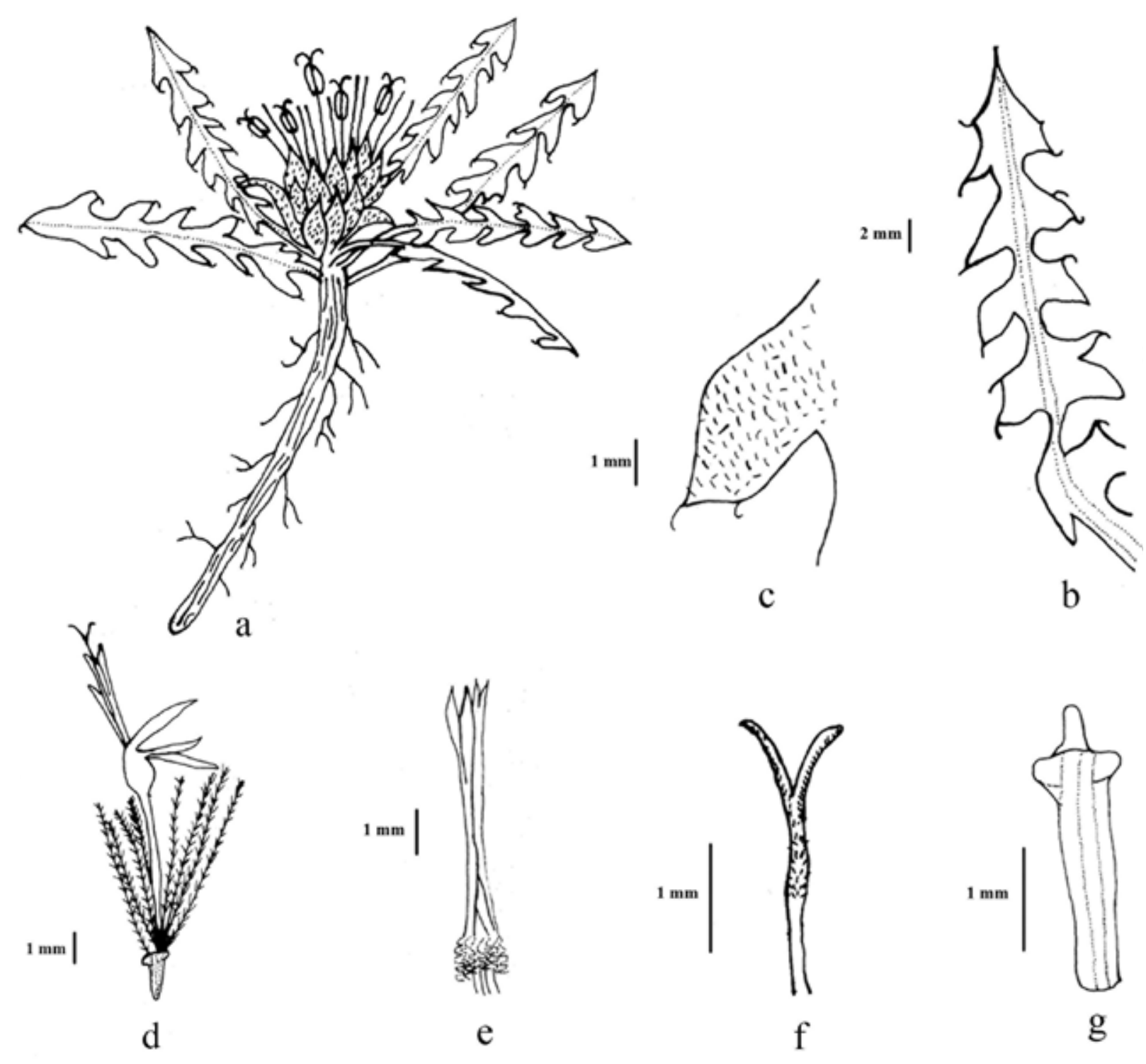

Fig 2. Saussurea andryaloides: a. Habit, b. Leaf, c. Enlarged portion of leaf with tomentose adaxial surface, d. Floret, e. Androecium, f. Stigma, g. Cypsela. (S. Kasana 1731, DUH). 
Specimens examined: INDIA, Uttarakhand, Rudraprayag district, Tungnath, $3421 \mathrm{~m}$, 30²9’24.83”N, 79¹3'1.89”E， 03.10.2017， S. Kasana 1716, 1717 (DUH); Tungnath, $3425 \mathrm{~m}$, 30²9’25.87”N, 79¹3’3.71”E, 03.10.2017, $S$. Kasana 1731 (DUH).

Conservation status: Saussurea andryaloides is widely distributed in China but is reported to be Rare in India and Pakistan (Butola \& Samant, 2011). The narrow blooming period and small size of the plant might be the reason why botanists have overlooked or misidentified the species.

Note: Detailed study of live and herbarium specimens showed that degree of hairiness on leaves varies considerably. Plants with wooly and pubescent to tomentose leaves are observed.

\section{Acknowledgements}

Thanks are due to Dr. Yousheng Chen, Institute of Botany, Chinese Academy of Sciences, Beijing, China for confirming the identity of the specimen. Authors are also thankful to Joint Directors of $\mathrm{DD}, \mathrm{BSD}$ and KASH for permission to consult the herbarium specimens. SK is thankful to the Council of Scientific and Industrial Research, New Delhi, India for the award of Junior Research Fellowship and Dr. S.S. Kambale, Arts, Commerce \& Science College, Tryambakeshwar, Nashik for helpful suggestions.

\section{Literature Cited}

BUTOLA J.S. \& S.S. SAMANT 2011. Saussurea species in Indian Himalayan Region: Diversity, distribution and indigenous uses. International Journal of Plant Biology 1(9): 43-51.

CANDOLLE A.P. DE 1838. Prodromus systematis naturalis regni vegetabilis, Volume 6 . Treuttel \& Wűrtz, Paris.

CHOWDHERY H.J. \& B.M. WADHWA 1984. Flora of Himachal Pradesh: Analysis. Botanical Survey of India, Kolkata.
CLARKE C.B. 1876. Compositae indicae descriptae et secus genera Benthamii ordinatae. Thacker, Sping \& Co., Kolkata.

DHAR U. \& P. KACHROO 1983. Alpine flora of Kashmir Himalaya. Scientific Publishers, Jodhpur.

HAJRA P.K. 1998. Brahmakamal and its allies: Saussurea, the genus. Jugal Kishore \& Co., Dehradun.

HOOKER J.D. 1881. Flora of the British India. L. Reeve \& Co., London.

KARTHIKEYAN S., SANJAPPA M. \& S. MURTHY 2009. Flowering Plants of India Dicotyledons. Botanical Survey of India, Kolkata.

LIPSCHITZ S.J. 1979. Rod Saussurea DC. (Asteraceae). Leningrad, Nauka.

PUSALKAR P.K. \& D.K. SINGH 2012. Flora of Gangotri National Park, Western Himalaya, India. Botanical Survey of India, Kolkata.

RAAB-STRAUBE E. VON 2017. Taxonomic revision of Saussurea subgenus Amphilaena (Compositae, Cardueae). Botanic Garden and Botanical Museum Berlin, Press, Berlin.

RAI I.D., SINGH G. \& G.S. RAWAT 2017. Plants of Kedarnath Wildlife Sanctuary, Western Himalaya: A field guide. Bishen Singh Mahendra Pal Singh, Dehradun.

SCHULTZ BIPONTINUS C.H. 1846. Bemerkungen zu der Cyanreen Less. Linnaea 19(3): 321-336.

SHARMA B.M. \& P.S. JAMWAL 1998. Flora of Upper Liddar Valleys of Kashmir Himalaya. Volume 2. Scientific Publishers, Jodhpur.

SHI Z. \& RAAB-STRAUBE E. VON 2011. Cardueae. Z.Y., WU, RAVEN, P.H. \& D.Y. Hong (eds.), Flora of China, Volume 20-21 (Asteraceae). Science Press, Beijing \& Missouri Botanical Garden Press, St. Louis.

UNIYAL B.P., SHARMA J.R., CHAUDHERY U. \& D.K. SINGH 2007. Flowering Plants of Uttarakhand (A Checklist). Bishen Singh Mahendra Pal Singh, Dehradun. 